\title{
PASSION, DUTY, AND FAME: WOMEN TRANSLATORS OF CUORE INTO ROMANIAN (1893-1936)
}

\author{
PAIXÃO, DEVER E FAMA: AS TRADUTORAS DE CUORE PARA O ROMENO \\ (1893-1936)
}

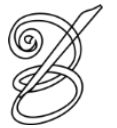 \\ Iulia COSMA* \\ West University of Timișoara \\ Timișoara, Romania \\ University of Padua \\ Padua, Padua, Italy
}

\begin{abstract}
The second half of the nineteenth century saw a proliferation of translations from romance languages into Romanian as a consequence of the economic and cultural development of the Romanian society. In this context, 1893 saw the publication of the first Romanian translation of De Amicis's Cuore (Heart): An Italian Schoolboy's Journal, by Clelia Bruzzesi (1836-1903). The twentieth century brought five other versions, two of them signed by women translators: Sofia Nădejde (1856-1946) in 1916 and Mia Frollo (1885-1962) in 1936. Until recently, Cuore was part of the primary school curriculum in Romania, so the text left a mark on the cultural history of the country. This paper aims to raise awareness of the often neglected translation activity of women and to reveal Bruzzesi, Nădejde and Frollo's place in society as well their motivations and the public reception of their translations.
\end{abstract}

Keywords: Women translators. De Amicis's Cuore (Heart): An Italian Schoolboy's Journal in Romanian translation. Literary translation into Romanian. Retranslation. History of literary translation.

Resumo: A segunda metade do século XIX viu uma proliferação de traduçães de línguas românicas para o romeno como consequência do desenvolvimento econômico e cultural da sociedade romena. Neste contexto, em 1893 foi publicada a primeira tradução romena de Cuore (Heart): An Italian Schoolboy's Journal [Coração: Diário de um aluno], de Amici, feita por Clelia Bruzzesi (1836-1903). No século XX, há outras cinco versões, duas delas assinadas por mulheres tradutoras: Sofia Nădejde (1856-1946), em 1916, e Mia Frollo (1885-1962), em 1936. Até recentemente, Cuore fazia parte do currículo do ensino fundamental na Romênia, por isso o texto deixou uma marca na história cultural do país. Este trabalho tem como objetivo sensibilizar as mulheres para a atividade de tradução muitas vezes negligenciada e revelar o lugar de Bruzzesi, Nădejde e Frollo na sociedade, bem como suas motivações e a recepção pública de suas traduções.

Palavras-chave: Tradutoras. Coração: diário de um aluno, de De Amici, em tradução para o romeno. Tradução literária em romeno. Retradução. História da tradução literária.

RECEBIDO EM: 3 de junho de 2019

ACEITO EM: 2 de agosto de 2019

PUBLICADO EM: abril 2020 


\section{Introduction}

ranslation has generally played a pivotal role in the birth and the development of
literary languages and national literatures. Romanian culture is no exception. However,
in the field of Romanian Translation Studies, not enough attention has been paid to translators in general and women translators in particular. This could be seen as a paradox, since decades ago influential scholars already insisted upon the importance of the human factor in translation (Robinson; Venuti; Pym), but not if it is correlated to what was identified as a more general lack of interest amongst Romanian scholars for the study of the translation process from a translatological perspective (Lungu Badea 8). My intention in this paper is to fill a gap since, to my knowledge, there is no study dedicated to the three women translators into Romanian of De Amici's novel, a book that was until recently part of the primary school curriculum and has thus left an important mark on my country's cultural history. Consequently, insofar as Romania's translation history is concerned, I aim at raising awareness about the necessity to give women translators their rightful place, without underplaying or exaggerating their role, but always in keeping with the deontological principles of a translation historian. My study covers 60 all three areas identified by Pym as part of translation history: 'archaeology', 'criticism', and 'explanation' (5), since it is my strong belief that to be relevant, research in this field must offer a thorough view on the translation activity by adopting an interdisciplinary approach.

\section{Cuore's First Translation into Romanian: 1893}

As historian Keith Hitchins well observes, the nineteenth century Romanian Principalities were marked by a controversy that rose among intellectuals regarding the present and the future development of their culture, a controversy that would continue for almost a century, right until the Second World War (Hitchins 12). At that time, it seemed their options were limited to choosing between, on the one hand, following the Western influence manifest on a material level by means of industrialisation and commerce, and on a cultural one by the political, literary and translation activity of young people, often from rich, aristocratic noble families, who had studied in Western Europe's prestigious universities, and, on the other hand, returning to the more conservative ways of rural traditions and Orthodoxism, oriented towards the past and the Slavic culture, traditions considered by some intellectuals as the real core of Romanian identity. Translation played an important part in the shift towards Western Europe and in the process of development of the Romanian literature and literary language, a process defined by scholars as one of "Re-Latinization", "Re-Romanization” (Pușcariu 434; Iordan 72), 
"Romance Westernization" (Niculescu 6-7) or "Francization" (Moldovanu-Cenușă 190). Therefore it is not surprising that translation had many detractors among those adhering to conservative views, such as historian and publicist Mihail Kogălniceanu who, strongly influenced by the above mentioned conflictual ideology, perceived translation only from the perspective of foreignization and subsequent destruction of a nascent national literature and national identity. His harsh criticism should not be dismissed easily, since translations were needed, no doubt about that, but, as Cornea points out, the criteria of selection was often determined not by quality standards or public interest and necessity, but by the client's and/or editor's will and economic prospects (Cornea 96). The result was the massive presence of romance novels and low culture literary products. Since some intellectuals were preoccupied with developing the public's cultural level by refining its literary and aesthetic taste, they started translating philosophy, scientific papers, and books for didactic purposes. In this context, in 1893, Clelia Bruzzesi published the first translation into Romanian of a popular children's book of that time by Italian author De Amicis, Cuore (Heart): An Italian Schoolboy's Journal: Cuore. Ce simte inima copiilor. Carte pentru copii [Cuore. What feelings children's hearts harbor. A children's book.], with an introduction by Alexandru Odobescu (1834-1895), an important intellectual and politician who was also the director of the National Educational Institute in Bucharest.

\section{Clelia Bruzzesi (1836-1903): an Industrious Promoter of the Italian Language and Culture}

Little is known today about Clelia Bruzzesi and not only because of gender iniquities. In my opinion, her nationality was another important factor that contributed to her oblivion. It is hard, if not impossible to know precisely when she got to the Principalities ${ }^{1}$, but since she attended the secondary school in Craiova ${ }^{2}$, it is safe to assume she was a preadolescent when she followed her family to a foreign land in search of a better life. That wasn't an uncommon situation in the second part of the nineteenth century, when Italian merchants, craftsmen, desperate peasants or just adventurers flooded towards more promising horizons, including the Romanian Principalities. Bruzzesi started working as an Italian teacher when she was seventeen (1853), at Wallachia's first boarding school for girls in Romanian, established in 1851 under the protection of the Știrbei royal family and functioning from 1852. The boarding school was for the offspring of the upper classes, limited to those who had proven themselves worthy subjects of the royal family (Rădulescu-Pogoneanu Școala Centrală 711). The fact that 
Bruzzesi obtained such an important position at a young age is not necessary an indication of her extraordinary abilities, but rather a consequence of her being a native speaker and of the interest of the Bucharest high society in the Italian language. Not knowing when she got married, and considering the fact that her husband was fourteen years older than her, I can't rule out that she may have been Mrs. Bruzzesi already at the time of the employment and that the husband's merchant profession could have played a part in her getting the job. Francesco Bruzzesi (18221894), a defender of Rome during the French siege of 1849 (Bezviconi 76), and a member of Garibaldi's army, was also the owner of a popular coffee house in Bucharest (Roșca). He developed a friendship with Marco Antonio Canini, another minor figure of the Italian Risorgimento and a political refugee in Wallachia, who was involved in cultural activities such as the translation of opera librettos in collaboration with political journalist I. G. Valentineanu, mainly for economic reasons ${ }^{3}$.

In 1888, Bruto Amante, an obscure writer and minor political figure, member in the cabinet of the Italian Ministry of Education, visited the Romanian Kingdom. The interest in the Romanian language had been instilled in him by his father, Errico, who had close contacts with 62 numerous intellectuals of the Principalities: Grigore Tocilescu, Aron Densuşianu, C.A. Rosetti, Remus Oprescu, I. Gh. Drăgescu, Petre Chiţu, Maria Chiţu ${ }^{4}$ (Anghel). The experience was narrated with enthusiasm in his La Romania illustrata. Ricordi di viaggio [Romania revealed. Travel memoirs]. According to him, Italian was extremely popular among Bucharest's elite and Miss Bruzzesi's teaching and translating activity contributed in a significant way to the promotion of Italian culture in the kingdom 5 . Furthermore, "her intellectual qualities, matched by exquisite spiritual gifts, have made her a loved and much revered person in Bucharest."6 (Amante 70) The husband is depicted as an example of rectitude, hard work, and professional ability, an honorable man whose life serves as a positive testimony on behalf of the Italian people $^{7}$ (Amante 71). Amante's opinions regarding the Bruzzesi family's importance might seem farfetched, or biased, since Clelia had translated into Romanian one of his books in 1885 , but shouldn't be dismissed entirely. I don't have sufficient information on Francesco Bruzzesi's commercial activity, but he seems to have been, at least for a short period of time, Consul of the young Italian Kingdom (Roșca). When it comes to Celia, she is mentioned as a translator in contexts related to cultural and high class society events, such as a lecture on Roman history and architecture given by Ioan Kalinderu in front of the Members of Romanian Academy on March 26, 1879 (Kalinderu 187), or the conference "Italy and Romania" presented by Pier Emilio Bosi, a young Italian lieutenant, at the Athénée Palace on January 20, 1909 (Bosi 281). 
Clelia contributed to a bimonthly magazine, "Trebuinciosul" [The Necessary], property of Luigi Cazzavilan (1852-1904), president of the Italian community and benefactor, another former member of Garibaldi's army, who had found refuge and good business in Bucharest, where he became one of the most influential figures in the publishing industry. "Trebuinciosul" was inspired by Italian magazines and aimed at entertaining its readers with translations from popular authors (Zăstroiu 1979: 860). Last, but not least, in 1903 Clelia Bruzzesi becomes the first woman on the Bucharest Committee of the Dante Alighieri Society, a prestigious position that comes as a confirmation of all her efforts to promote Italian culture. Since she proved to be an important cultural figure, why was she left out of dictionaries and literary histories, unlike other minor women translators? More than the general lack of interest in translation that I mentioned at the beginning of this sub section, I believe the main reason to be her nationality. She was not Romanian, so there was no place for her in dictionaries or literary histories. Since she translated mostly into Romanian, I argue that her activity should be considered part of the Romanian history of translation and it is high time to recognize her merits and her rightful place amongst other translators whose activities have proven to be fundamental for the development of Romanian culture.

\section{Twentieth Century Retranslations}

The beginning of the twentieth century sees the publication of two retranslations of Cuore, one by Sofia Nădejde in 1916 and another one by Mia Frollo in 1936. According to Keith Hitchins, the Romanian intellectuals of that period were still divided into two fields, the same as during the second half of the nineteenth century: the Europeanists and the traditionalists (Hitchins 315), with no intention of finding a common ground. So, apart from the intensification of some antidemocratic tendencies (Hitchins 429-32), there weren't any significant cultural and ideological changes that could have justified the need for a retranslation. The situation is the same as far as language evolution is concerned: no fundamental innovation to be registered. When compared, the three versions are similar, without any notable differences. It is common knowledge that subjectivity marks the translation process and any retranslation is inherently different from the anterior version, so if the researcher limits himself/herself at registering those discrepancies, s/he is not contributing to the development of knowledge. In my opinion, what's relevant when it comes to retranslation is the understanding of the translator's motivations for engaging in such process in the first place: it can be a question of revising a flawed version, of an affinity for a certain author and/or topic, of a change in ideology or language policies, or of 
material interest. In order to understand the motivations behind these particular retranslations, we must first take into account Nădejde’s and Frollo’s biography.

\section{Sofia Nădejde (1856-1946): a Romanian Pioneer for Women's Rights and Education}

Sofia Nădejde, née Băncilă-Gheorghiu, was an influential intellectual of her time: a writer, a translator, a feminist, and social activist. Still, much like Bruzzesi's, her merits have been forgotten or neglected. Regardless of her inclusion in dictionaries published during the communist regime, most likely because of her being a socialist, and Victor Vișinescu's 1968 anthology of her literary and journalistic works entitled Din chinurile vieții [Of life's sorrows], she remains an obscure figure of Romanian literary and cultural history.

Nădejde studied at a private boarding school in Botoșani, a provincial town, but sat her high school exit exam in Iași, where she followed her husband, a teacher and one of the leaders of the Romanian socialist movement. A mother of six, she was involved in numerous activities for the benefit of women and was also preoccupied with the scientific and cultural enrichment of the working class. Some of her works were published under various pseudonyms: Eva,

64 Elisabeta, Sorina, Sonia, Vanda D, G. S., S. G. (Drăgoi 608).

Her journalistic activity is quite impressive, since she contributed to various contemporary political and cultural journals and newspapers like „Contemporanul” [The Contemporary], „Drepturile omului” [Human Rights], „Muncitorul”[The Worker], „Literatură și știință’[Literature and Science], „Munca”[The Work], „Gazeta săteanului”[The Villager's Gazette] and others. In 1894 she became the first Romanian woman to be head of a newspaper, „Evenimentul literar” [Literary Event], and in 1897 she held the position of president for the Fourth Congress of the Romanian Workers Social-Democratic Party. However, her independence seems to have been limited by her husband's decisions, since she followed him in leaving the social movement in 1897. The relationship between the two, as depicted by Izabela Sadoveanu (in Atanasiu 1932: 368-72), sister in law of the famous writer Mihail Sadoveanu and close collaborator of Sofia Nădejde, was almost a symbiotic one (in Atanasiu 1932: 370), as they were partners in life and politics, but respected the traditional roles of the dedicated mother and faithful wife and of the paterfamilias. Izabela's representation of Sofia Nădejde could seem contradictory, since she is described as

uncomplicated like a child, with a lot of common sense like a peasant of sound mind and body; original, passionate and excessive like a true feminine spirit in all its manifestations. Her broad culture, undying interest for science, and intellectual 
activity cast a light on the qualities of a strong, plural and yet differentiated personality. ${ }^{8}$ (in Atanasiu 1932: 371)

In reality, it is an indication of an incipient form of feminism, characterized by a tendency to compromise and not to question traditional roles.

One of the most interesting aspects of Nădejde's feminist activism is the controversy she engaged in with the most influential literary critic of her time, Titu Maiorescu, a brilliant aesthetician, who, following Schopenhauer and Comte, embraced a narrow view on women, considering them inferior to men in terms of intellectual capacity. In order to prove her point, Nădejde responded with arguments extracted from important authors like H. Spencer and J. Stuart Mill (Botez and Pop 295). Attacking Maiorescu's unfortunate convictions was an act of intellectual bravery and could be interpreted in light of the important position she acquired in the political and cultural press of her time.

During the First World War she sought refuge near Odessa, where she presumably worked on the retranslation of Cuore, published in Romania in 1916, while she was still abroad. A year before that, she had translated a novel by Matilde Serao, Italy's first woman head of a newspaper. As mentioned previously, Nădejde's fortune wasn't much different from that of Bruzzesi's. The communist regime didn't turn her into an iconic figure, probably because, after all, even if she had been a mother of six and a socialist in contact with Russian intellectuals, she didn't quite incarnate the feminine ideal promoted by the party's ideologists: too independent and strongminded.

\section{Mia Frollo (1885-1962): a Lady of the Literary Society and Catholic Circles}

Mia Frollo was not Italian; she just changed her maiden name, Maria Buzoianu, to her husband's, Iosif Frollo, a university professor, son of the more famous Giovanni Luigi Frollo, Italian teacher and author of an Italian grammar and a Romanian-Italian Dictionary, Vocabolario italiano-romanesco (1869). Mia Frollo was a minor writer that frequented the most important literary circle of her time, Lovinescu's Circle, run by influential critic Eugen Lovinescu. She wrote for cultural magazines and published translations under various pseudonyms: Mia Vlad, Adhemar (used probably when collaborating with Ovid Densusianu) Cery, Amy, Miriam (Durnea 199). Unlike the other women translators, she graduated from the Faculty of Letters and Philosophy of Bucharest in 1919 at age 34. One cannot ignore that her husband was a professor and so she could have obtained preferential treatment during the five years spent taking university courses. After graduation, aside from her writing and translating 
activity, she taught French and Romanian in different schools. Thanks to her husband's connections, she frequented the most powerful members of the Italian community, such as Ramiro Ortiz, professor of Italian at the University, and the catholic circles. Iosif Frollo was a fervent catholic and a Romanian Legionary Movement sympathizer. For him, unlike other farright intellectuals and Iron Guard ${ }^{9}$ supporters, being a true Romanian had nothing to do with Orthodoxism. He even engaged in a controversy on the matter with a university colleague, the philosopher Nae Ionescu, who professed the necessity of returning to Orthodoxism as inherent to the Romanian way of life and spirituality (Hitchins 339). Nae Ionescu was a charismatic figure adored by his students, the equivalent of a guru for Mircea Eliade and Emil Cioran's generation. The debate between Iosif Frollo and Nae Ionescu, who used the pseudonym Părintele Scriban [Father Scriban], took place in 1930 in the pages of the "Cuvântul" [The Word] newspaper, but a year later, Frollo decided ${ }^{10}$ to gather his texts in a volume titled Romînism și Catolicism [Romanianism and Catholicism].

Mia Frollo had much to gain from her husband's position. She became a close contributor to the bimonthly journal "Vieața Nouă" [The New Life], which focused on literary 66 criticism and the foreign influences on the development of Romanian literature (Zăstroiu 904) and where she published translations from Dante's Inferno and other authors. In 1921, during the six hundredth anniversary of Dante's death, she was one of the two key speakers, alongside Ovid Densusianu, a philologist, linguist, university professor, member of the Romanian Academy and director of "Vieața Nouă". Mia Frollo held two public conferences on July 7 and 11: one dedicated to Dante and Florence and the other to the Commedia. During the festivities, some of her and Densusianu's translations from Dante's works were read (Speranția 108). In 1936, when she published her retranslation of Cuore, she got the endorsement of the Ministry of Education, which authorized her version for general use in schools with Order no. 11 issued on January 18, 1936. The volume contains an excerpt from the endorsement speech prepared by a certain I. Garabet, Romanian teacher at the Cantemir Vodă National College, who deems her translation to be the best one (De Amicis 9). There is no mention of the previous translators' names, as testimony to the orator's little interest and consideration for their work.

In order to get a better understanding of Mia Frollo's personality, we must take into account a memory from Nicolae Steinhardt's first participation in the Lovinescu's Circle in 1929 and an article she published in "Flori de crin" [Lilies] in 1933. Steinhardt's first impression is that of a young man of seventeen, and it has a rather anecdotal value, but in my 
opinion, it is a significant testimony regarding her temper: "Mia Frollo - big lady with huge hair and extremely agitated"11 (Steinhardt 227).

"Flori de crin" was a women's magazine edited in Transylvania, but it had nothing to do with emancipation or empowerment; quite the opposite, since its goal was marked by Catholic rhetoric: "To protect young women - and woman in general - from deadly immorality $^{12}$. [...] to give Christian advice to mothers $\left.[\ldots]\right]^{13}$ (Flori $\left.{ }^{14} 2\right)$. In her article, Mia Frollo insists on the downsides of feminism, using a lot of clichés, such as lack of femininity and charm - an extremely important quality in her opinion - and sterile hearts, hardened by intellectual speculations (Frollo 1933: 3). Women had got enough rights, but lost their true nature in the process, so it was high time for them to stop fighting and take a step back. (Frollo 1933: 3). She continues with an apology of Hitler and Mussolini, providential leaders that have stopped the moral decay of their peoples, by fighting the laicization process brought about by Freemasonry (Frollo 1933: 3). I am not bringing this article to the reader's attention in order to criticize Mia Frollo's ideology. As far as I'm concerned, it is just a powerful argument in favor of my suppositions regarding the importance of her husband's involvement in her literary and translation activity. As for her posthumous destiny, she shares the same fate as the women translators before her.

\section{Motivations ${ }^{15}$}

Unlike Sofia Nădejde, Clelia Bruzzesi and Mia Frollo voiced their reasons for having translated Cuore. For Clelia it came as a natural consequence of her teaching experience, since she had spent most of her life amongst young pupils, trying to give them good advice (Bruzzesi 5). Much appreciating De Amici's work, she considered it useful for both children and parents because of its pedagogical value and the importance given to righteous feelings (Bruzzesi 5). She ended her note with a topos of the translation discourse, the request for the reader's good will and clemency for her work (Bruzzesi 5). Clelia Bruzzesi's translation was much needed, since there was a lack of school text books in Romanian. For Rădulescu-Pogoneanu, it could have been a happy coincidence that led to Odobescu's introduction to Clelia's translation, as he himself, in collaboration with the most important Romanian novelist of the time, Ioan Slavici, was involved in the making of a reading syllabus for elementary schools (Rădulescu-Pogoneanu Activitatea 97).

Sofia Nădejde's retranslation was probably done during her stay in Kerson, near Odessa, under Russian occupation, a few years after she quit the Romanian Socialist Movement. In 
times of war, we can't rule out the material factor, or the ideological one. De Amicis was a socialist and although Cuore had been written before his joining to the Party, for Sofia translating could have been a way of doing something for the movement or, since she was an active feminist, contributing to the cause, even if the female characters in Cuore played traditional roles and were not strong, independent figures. Then again, if we consider Izabela Sadoveanu's characterization of Nădejde's personality, we can find some common traits with the main character Enrico Bottini's mother and teachers.

Mia Frollo begins her preface by expressing how much she enjoyed translating this famous book and continues by justifying some of her translation choices: keeping the title of the original (Frollo 7) and preferring the Romanian equivalent of professor for the Italian maestro, used for an elementary school teacher, since Romanian pupils use maestru [maestro] only for music and drawing teachers and the potential readers are mostly in high school, therefore accustomed to profesor [teacher] (Frollo 8). It is a surprising choice, to say the least, since she could have used învățător, indicating an elementary teacher, but it is revealing of her translation method, an excessively literal one with a tendency towards naturalization. There is no mention of the previous versions or any reason for the necessity of a second retranslation. As for what she thinks of De Amici's work, there's one negative aspect, namely the lack of religious sentiment, which Mia Frollo attributes to his generation's intense political activity, the generation of Cavour, Mazzini and Garibaldi, that put patriotism above all else and got so caught up in its fight for national unity, that forgot to give God his rightful place (Frollo 7). The negative interpretation of De Amici's secular perspective in Cuore is not surprising if we consider her participation in catholic circles and her husband's sympathies for the Legion. In my opinion, she retranslated the book because it was still popular and she probably hoped that some of that fame would rub off on her, increasing her visibility in the literary society. The material aspect cannot be ruled out.

\section{Conclusions}

The women translators of Cuore' had a lot in common: they were all married to important husbands and had an interest in intellectual and literary activities. Clelia Bruzzesi and Mia Frollo were teachers and promoters of the Italian language and culture and members of Bucharest's good society, while Nădejde was a socialist and an active feminist. What distinguishes Clelia Bruzzesi and Sofia Nădejde from Mia Frollo is the impact of ideology on their cultural and translational activity: the first two were dedicated to teaching or empowering 
the less fortunate, while the latter was under the strong influence of Iosif Frollo's Catholic and far-right nationalistic sympathies. When it comes to their husbands' support, Nădejde benefitted the least, while Frollo owed a lot to his position at the university and his political connections.

Once important cultural and literary activists, appreciated and revered, they became obscure figures in dictionaries or literary memoirs that nobody reads anymore. They should be given their deserved place in Romania's translation and cultural history: posterity owes them as much.

\section{REFERENCES}

Amante, Bruto. La Romania illustrata. Ricordi di viaggio, Roma, Bruto Amante Editore, 1888.

Anghel, Ioana. Errico e Bruto Amante - ricordi sul Risorgimento italiano e romeno, 2013. http://www.rri.ro/it_it/errico_e_bruto_amante_ricordi_sul_risorgimento_italiano_e_romeno8622.

Atanasiu, I. C. Mișcarea socialistă 1881-1900, vol. I, București, Editura Adevărul, 1932.

Bezviconi, Gheorghe. Necropola capitalei, București, Institutul de Istorie "Nicolae Iorga“", 1972.

Bosi, Pier Emilio. "Italia și România", trans. Clelia Bruzzesi, Literatură și Artă, 5 (19001901), 1901, pp. 281-292.

Botez, V., and Pop, L. "Literatura pentru emanciparea femeii la „Contemporanul”: Sofia Nădejde”, Studii și cercetări științifice. Fiologie. Filiala Iași, VIII (2), 1957, pp. 293-310.

Bruzzesi, Clelia. "Notița traducătoarei”, in De Amicis, Edmondo Cuore. Ce simte inima copiilor. Carte pentru copii, trans. Clelia Bruzzesi, $11^{\text {th }}$ Edition. București, „Cartea Românească”, 1943 , p. 5.

Cornea, Paul. De la Alexandrescu la Eminescu, București, Editura pentru Literatură, 1966.

Cosma, Iulia. "The translation of Italian opera librettos in the nineteenth century: historical and cultural milestones", Translationes 6, 2014, pp. 78-92.

https://www.academia.edu/16071859/The_translation_of_Italian_opera_librettos_in_the_nine teenth_century_historical_and_cultural_milestones.

Cosma, Iulia. "Le sfide della traduzione di Cuore in romeno (1893-1936)", Translationes 9 , 2017, pp. 98-113.

https://www.academia.edu/34695935/Le_sfide_della_traduzione_di_Cuore_in_romeno_18931936 
De Amicis, Edmondo. Cuore Inimă. Carte pentru tineri, trans. Sofia Nădejde, $2^{\text {nd }}$ Edition, București, „Cultura Românească”, $1935^{16}$ [1916].

De Amicis, Edmondo. Cuore, trans. Mia Frollo, București, Editura Cugetarea - Georgescu Delafras - S. A, 1936.

De Amicis, Edmondo. Cuore. Ce simte inima copiilor. Carte pentru copii, trans. Clelia Bruzzesi $11^{\text {th }}$ Edition, București, „Cartea Românească”, 1943 [1893].

Drăgoi, Gabriela. "Sofia Nădejde", in Dicționarul literaturii române de la origini până la 1900, București, Editura Academiei Republicii Socialiste România, 1979, pp. 607-609.

Durnea, Victor. "Mia Frollo", in Dicționarul general al literaturii române, vol. III E-K, București, Editura Univers Enciclopedic, 2005, p. 199.

Frollo, Iosif. Romînism și Catolicism, București, Tipografia Bucovina, 1931.

Frollo, Mia. "Maicile mici ale săracilor”, Flori de crin, 1933, pp. 5-6; 3-4.

Frollo, Mia. "Prefață". De Amicis, Edmondo Cuore, trans. Mia Frollo, București, Editura Cugetarea - Georgescu Delafras - S. A, 1936, pp. 7-8.

70 Iordan, Iorgu. "Importanța limbii române pentru studiile de lingvistică romanică ". Actele celui de-al XII-lea Congres internațional de Lingvistică şi Filologie Romanică, II, edited by Rosetti, Al. București, Editura Academiei Republicii Socialiste România, 1970, pp. 67-76.

Istrate, Ion. Romanul italian în România (1843-1989). O exegeză bibliografică, Pitești, Paralela 45, 2007.

Kalinderu, Ioan. “August și literații”. Analele Academiei Române. Seria II. Tomul XIX. Memoriile Secțiunei Istorice, Bucuresci, Institutul de Arte Grafice Carol Göbl, 1897, pp. 161192.

Hitchins, Keith. România 1866-1947, trans. George G. Potra and Delia Răzdolescu, București, Humanitas, 1996.

Lungu Badea, Georgiana. Idei și metaidei traductive românești (secolele XVI-XXI), Timișoara, Eurostampa, 2013.

Moldovanu-Cenușă, Ioana. "Influența franceză în cadrul arhitecturii limbii române. Teoria „relatinizării” sau a „reromanizării” ”, Philologica Jassyensia IX, 1(17), 2013, pp. 183-194.

Nădejde, Sofia. Din chinurile vieții, Victor Vișinescu (ed.), București, Editura pentru Literatură, 1968.

Niculescu, Alexandru. Individualitatea limbii române între limbile romanice. II, București, Editura Ştiințifică și Pedagogică, 1978.

Pușcariu, Sextil. Cercetări și studii, București, Minerva, 1974. 
Pym, Anthony. Method in Translation History, London and New York, Routledge, 2014 [1998].

Rădulescu-Pogoneanu, I. A. “Activitatea pedagogică a lui Alexandru Odobescu”. RădulescuPogoneanu, I. A., Studii. București, Institutul de de Arte Grafice Carol Göbl și Ioan St. Rasidescu, 1910, pp. 86-108.

Rădulescu-Pogoneanu, I. A. "Școala Centrală de fete din București”. Boabe de grâu 5 (12), 1934, pp. 705-753.

Robinson, Douglas. The Translator's Turn, Baltimore and London, The John Hopkins UP, 1991.

Roșca, Dan. Lângă Grădina Episcopiei, acum un veac, 2011.

http://www.bucurestiivechisinoi.ro/2011/12/langa-gradina-episcopiei-acum-un-veac/.

Speranția, Eugeniu. "Însemnări despre revista Vieața Nouă. Mărturiile unui colaborator". Ovid Densusianu în amintirea şi conştiinţa critică românească , Edited by Diaconu, I., Șerb, I., București, Editura “Grai şi suflet” - Cultura Naţională, 2005, pp. 105-110.

Steinhardt, Nicolae. "Nu departe de E. Lovinescu". Steinhardt, Nicolae Prin alții spre sine, Iași, Polirom, 2012, pp. 226-231.

Venuti, Lawrence. The Translator's Invisibility, London and New York, Routledge, 1995.

Zăstroiu, Remus. "Trebuinciosul”, in Dicționarul literaturii române de la origini până la 1900, București, Editura Academiei Republicii Socialiste România, 1979, p. 860.

Zăstroiu, Remus. "Vieața Nouă”. Dicționarul literaturii române de la origini până la 1900, București, Editura Academiei Republicii Socialiste România, 1979, pp. 904-905.

\footnotetext{
${ }^{*}$ Iulia COSMA - PhD in Philology (2012) and a Post-doctoral degree (2015) both by West University of Timisoara Senior lecturer at the Department of Modern Languages and Literatures, West University of Timisoara. She is currently a Romanian lecturer at the Department of Linguistic and Literary Studies, University of Padua. West University of Timișoara, Department of Modern Languages and Literatures. Timișoara, Romania. University of Padua, Department of Linguistic and Literary Studies. Padua, Padua, Italy.

Academia.edu: https://uvt-ro.academia.edu/IuliaCosma/CurriculumVitae

ORCID: https://orcid.org/0000-0002-1663-3895

E-mail: iulia.cosma@e-uvt.ro

${ }^{1}$ To complicate the situation even more, there is no mention of her maiden name.

2 The information about her education and teaching career comes from the note she included before Odobescu's introduction. Unfortunately, she does not mention when and for how long she attended school in Craiova.

${ }^{3}$ For more data on Canini and arguments sustaining my assertion on his economical interest, see my paper "The translation of Italian opera librettos in the ninteenth century: historical and cultural milestones " (Cosma The translation 78-92), available on www.acecademia.edu.

${ }^{4}$ Maria Chițu or Chițiu was the first to completely translate Dante's Inferno in Romanian.

5 "Bucarest è ricca d'istituti pubblici d'istruzione e di educazione. La lingua italiana è insegnata come materia obbligatoria ne'licei. Anzi trovai affidato quest'insegnamento per la scuola festiva delle fanciulle ad una signora italiana, la Clelia Bruzzesi. Una parola speciale di ricordo e di encomio merita questa nostra concittadina. La Bruzzesi ha educato moltissime giovani dell'aristocrazia romena alla conoscenza ed all'amore della nostra lingua,
} 
che insegna con sincero affetto di patria e con singolare perizia. Essa ha diffuso tra' romeni la conoscenza de' nostri migliori scrittori popolari. Tradusse in romeno le Mie Prigioni di Silvio Pellico, molti brani de' Promessi Sposi del Manzoni e viceversa dal romeno in italiano un lavoro drammatico dell'Urechia (Elisa) ed ha dato e dà prova di grande operosità.“ (Amante 70)

${ }^{6}$ The English version of all quotes from Italian and Romanian belongs to the author of the paper. - "A queste qualità intellettuali accoppia squisite doti di animo, per cui è amata e venerata grandemente in Bucarest." (Amante 71)

7 "Il marito, il cav. Francesco Bruzzesi, è uno de' più accreditati commercianti di Bucarest e colla rettitudine della vita e coll'attività ben indirizzata negli affari ha contribuito ad accrescere stima ed affetto al nome italiano." (Amante 71)

${ }^{8}$ The English version of all quotes from Italian and Romanian belongs to the author of the paper. "simplă ca un copil, plină de bun simț ca o țărancă sănătoasă la trup și la minte, personală, pasionată şi excesivă ca o adevărată fire femenină în toate manifestările ei. Vasta ei cultură, interesul nesecat pentru știință și lucrurile intelectuale nau făcut de cât să lumineze calităţile unei puternice, multiple și diferențiate individualităţi.“

${ }^{9}$ Established in 1930, the Iron Guard was the military wing of the Legion of the Archangel Michael, better known as the Legion or the Legionary Movement, a Romanian fascist organization founded in 1927 by Corneliu Zelea Codreanu, which promoted a mystical nationalism and a virulent anti-Semitism. Their leader was perceived as a messianic figure supposed to bring a fundamental change in Romania by returning to Orthodoxism and purging the society of any foreign elements.

${ }^{10}$ Iosif Frollo opens his book by clarifying the reasons for its publication: first, his friends' numerous requests of newspaper issues they had missed, second, the length of his interventions criticized by Nae Ionescu, and last but not least, the necessity to give homogeneity to a discourse that, even if published in response to an interlocutor, had a common core, namely fighting the prejudice according to which nationality and religion were one, meaning that only an Orthodox could be a true Romanian (Frollo 3).

11 „Mia Frollo - ditai doamna cu părul cât o claie și foarte agitată”.

${ }^{12}$ Emphasis in the original (2).

7213 ,Să apere tineretul feminin - și femeia în general - de imoralitatea ucigașă. [...] să dea sfaturi creștinești pentru mame".

14 There is no author indicated.

${ }^{15}$ Excerpts from this section were elaborated and published in a paper on the difficulties of translating Cuore into Romanian (Cosma Le sfide 103-104).

${ }^{16}$ In Romanul italian în România (1843-1989). O exegeză bibliografică, the second edition of Nădejde's retranslation is placed in 1943 (Istrate 86). However, I acquired an old copy by the same Publishing House with no time indication, except for a reader's name and a date: 1935. After confronting the cover with others by the same Publishing House from the Thirties and the Fourties, and considering the Order issued by the Ministry of Education in 1936 in favour of Frollo's translation, I decided to validate the reader's testimony. 